\title{
Cyanobacteria abundance and its relationship to water quality in the Mid-Cross River floodplain, Nigeria
}

\author{
Okogwu Okechukwu I. ${ }^{1} \&$ Ugwumba Alex O. ${ }^{2}$ \\ 1. Applied Biology Department, Ebonyi State University, PMB 53, Abakaliki, Ebonyi State, Nigeria; \\ okeyokogwu@yahoo.com \\ 2. Zoology Department, University of Ibadan, Ibadan, Oyo State, Nigeria; adiaha4me@yahoo.co.nz
}

\author{
Received 14-III-2008. Corrected 15-VII-2008. Accepted 17-VIII-2008.
}

\begin{abstract}
The physicochemical variables and cyanobacteria of Mid-Cross River, Nigeria, were studied in six stations between March 2005 and August 2006 to determine the relationship between water quality and cyanobacteria abundance. Canonical Correspondence Analysis (CCA) showed that biological oxygen demand (BOD), dissolved oxygen, $\mathrm{pH}$, water velocity, width and depth were important environmental factors that influenced cyanobacteria abundance. Trace metals, phosphate and nitrate increased significantly from values of previous studies indicating increased eutrophication of the river but were weakly correlated with cyanobacteria abundance and could be scarcely regarded as regulating factors. A higher cyanobacteria abundance was recorded during the wet season in most of the sampled stations. The dominant cyanobacteria included Microcystis aeruginosa, Aphanizomenon flos-aquae, Oscillatoria limnetica and Anabaena spiroides. The toxins produced by these species could degrade water quality. The factors favouring cyanobacteria abundance were identified as increased $\mathrm{pH}$, width and depth. Increase in cyanobacteria abundance was associated with reduction in dissolved oxygen and increase in BOD values. Rev. Biol. Trop. 57 (1-2): 33-43. Epub 2009 June 30.
\end{abstract}

Key words: Cross River, floodplain, cyanobacteria, water quality, Nigeria.

Cyanobacteria in water pose a serious concern, as they can be harmful in several ways. Their blooms reduce the aesthetic value of recreational water, decaying algal blooms may result in anoxia, due to high biological activity, and may lead to mortality of fish and other aquatic organisms. The toxins they produce could harm several aquatic organisms, birds and man (Richardson 1997).

The genus of most concern for toxin production is the cosmopolitan Microcystis, predominantly Microcystis aeruginosa, with other genera being Oscillatoria, Anabaena, Aphanizomenon and Nodularia. Where climate and other environmental factors permit, there may be continuous water blooms of toxic cyanobacteria in surface water. The dominance of cyanobacteria may be due to their low need for uptake of nutrients during the benthic life phase additionally, buoyancy control, tolerance to high temperature and $\mathrm{pH}$, release of allelopathic compounds, grazing resistance and phosphorous and nitrogen storing (Keating 1977, Smith 1986, Reynolds et al. 1987, Robarts and Zohary 1987, Sterner 1989, Shapiro 1990, Blomqvist et al. 1994, Hyenstrand et al. 1998, Mur et al. 1999, Mitrovic et al. 2001, Hanson et al. 2007).

Cyanobacteria can produce both hepatotoxic peptides which cause liver damage and are tumor-inducing e.g. microcystin (produced by M. aeruginosa) as well as neurotoxic alkaloids e.g. aphanotoxin from Aphanizomenon flosaquae and anatoxin-a produced by Anabaena and Oscillatoria (Pushparaj 1999, Lansberg 2002, Lehtiniemi et al. 2002, Koslowsky- 
Suzuki et al. 2003, Suikkanen et al. 2004, Karjaleinen et al. 2005, Oberholster et al. 2005, Hannson et al. 2007). These toxins are known to also have allelopathic effect and could inhibit the growth of other phytoplankton as well as harm zooplankton and fish (Nizan et al. 1986, DeMott and Moxter 1991, KoslowskySuzuki, et al. 2003, Suikkanen et al. 2004). Some of these toxins can cause skin irritation in human swimmers (Pushparaj 1999). High toxin production is usually associated with increased density of cyanobacteria in freshwater (Visser et al. 2005).

In Nigeria, cyanobacteria have been given little attention despite their occurrence in several rivers and lakes (Ugwumba and Ugwumba 1993, Akin-Oriola 2003, Okogwu and Ugwumba 2006). The Cross River is about the fifth longest river in Nigeria and is of notable economic, ecological and cultural significance but there is dearth of information on its phytoplankton composition. Domestic water supply to Afikpo town and it's environ is sourced from the Cross River. Yearly fish and shrimp production in the Cross River basin is about 8000 tonnes and 2000 tonnes respectively and it is one of the richest in Nigeria (Akpan and Offem 1993). Fish production in the Cross River is highly dependent on seasonal fish breeding in the floodplains during the wet season. Juvenile fish and shrimp are known to be highly susceptible to cyanobacterial toxins. Karjalainen et al. (2005) reported reduced feeding rate of larval fish exposed to cyanobacterial toxin. Therefore, knowledge of the spatio-seasonal abundance of cyanobacteria in relation to water quality will be invaluable in adopting sustainable strategy in the management of the fisheries of Cross River. This paper focuses on the cyanobacteria abundance of Mid-Cross River floodplain ecosystem, a source of municipal water and region of high fisheries and recreational activities.

\section{MATERIALS AND METHODS}

Study area. Cross River system lies approximately between longitude $3^{\circ} 30^{\prime} \mathrm{E}$ and $10^{\circ} 00^{\prime} \mathrm{E}$ and latitude $4^{\circ} \mathrm{N}$ and $8^{\circ} \mathrm{N}$. The river basin covers an area of $54000 \mathrm{~km}^{2}$ with 14 $000 \mathrm{~km}^{2}$ in the Cameroon and $39500 \mathrm{~km}^{2}$ in Southern Nigeria. It empties into the Atlantic Ocean. The dry season starts from November and lasts till the end of March. The wet season is between April and October. Maximum precipitation (about $70 \%$ of the total) occurs between June and October. Rainfall is all year round with annual total of $290 \mathrm{~cm}$. At the onset of rainy season, the water level in the river starts to rise gradually from the dry season level. By the third week of June the rise is rather sharp then drops slightly during August break. The level of water rises again in September to a maximum in the middle of October (when lakes within the floodplains are connected to the river), and then drops rapidly by the middle of November and continuously falls to the minimum dry season level.

The climate is tropical. Temperature variation within the basin is slight $\left(27.5^{\circ} \mathrm{C}-33.0^{\circ} \mathrm{C}\right.$ maximum; $22.5^{\circ} \mathrm{C}-24.0^{\circ} \mathrm{C}$ minimum). The annual range is about $7.0^{\circ} \mathrm{C}$. The relative humidity is high throughout the year particularly in the coastal area (93\%). The flood regime of the river is strongly linked to the climatic factors. Mean annual discharge at Obubra is $995 \mathrm{~m}^{3} \mathrm{~s}^{-1}$ with minimum and maximum values of $80 \mathrm{~m}^{3} \mathrm{~s}^{-1}$ (February) and $3300 \mathrm{~m}^{3} \mathrm{~s}^{-1}$ (September) respectively (Moses 1979).

Six stations were sampled, Station I (Itigidi) is a major water transport route between Cross River State and Ebonyi State. It is also a source of municipal water supply. Minor dredging activity takes place in this station. Station II (Ozziza) is a minor transport rout, domestic activities like washing of clothes, kitchen utensils and swimming take place here. Station III (Ndibe) is a major commuters' and wood transport route. Dredging activities also take place here during the dry season due to the appearance of sand bank, which also attracts a lot of recreational activities to the site. Stations IV and V (Iyieke and Ehoma) are shallow lakes located on the Cross River floodplain. Local inhabitants conserve the fishery resources of the lakes. The lakes are fished once in a year 
in February or March each year. The banks of the lakes are well vegetated. Although there is a high deforestation activity going on around the banks. During the dry season aquatic weeds appear on these lakes. The stations are in close proximity to farm lands and parts of these lakes are usually cultivated during the periods when water recedes in the dry season. Station VI (Unwana) is a source of municipal water supply with low fishing activities. Limited dredging and recreational activities take place here.

Sampling and analysis. The transparency of the water was measured using $15 \mathrm{~cm}$ diameter white secchi disc. Temperature, dissolved oxygen, $\mathrm{pH}$, conductivity and total dissolved solid (TDS) were determined in situ using HANNA field meters. The depth of the water was measured at each station using a fortified secchi disc. The width of the river at each station was taken by running a builder's line from one bank of the river to the other. The surface water current velocity was determined according to Maitland (1978) using a half submerged float made of weighted cork.

Water samples for chemical analysis were collected in 1.5 L plastic containers samples were collected at each station from the surface and a depth of $2 \mathrm{~m}$ from the surface and these were pooled together for a given station. Samples for metal analysis were collected separately in $1 \mathrm{~L}$ plastic containers and preserved using $1.5 \mathrm{~mL}$ conc. nitric acid $\left(\mathrm{HNO}_{3}\right)$ per litre of sample. Iron, copper and zinc were analysed using Perkin Elmer Atomic Absorption Spectrometer (AAS) (Model 403) according to the standard methods of APHA (1992). Nitrate and phosphate were determined by colorimetric method (APHA 1992).

Phytoplankton samples were collected using $45 \mu \mathrm{m}$ mesh size silk plankton net and were preserved in $4 \%$ buffered formalin. Enumeration of phytoplankton was done according to Ovie (1997) using SedgwickRafter counting chamber. A minimum of three subsequent sub-samples was counted and the mean value for each identified organism used to estimate abundance of the species.
Analysis of variance (ANOVA) was used to test for significant difference in spatial and temporal variation in environmental and biological data. Canonical correspondence analysis (CCA) was used to evaluate cyanobacteria-environment relationship. All data were first transformed logarithmically using the formula $\log (\mathrm{x}+1)$ before CCA was applied. All statistical analyses were carried out using the PC-ORD and Statistical package for social science (SPSS) softwares.

\section{RESULTS}

Table 1 shows the mean and ranges of the physiochemical parameters. Dissolved oxygen, depth, biological oxygen demand, river width, nitrate, phosphate and water velocity showed remarkable significant seasonal and spatial variation $(\mathrm{p}<0.05)$ during the study. The wide variation in $\mathrm{pH}$ (5.6-7.8) was due to neutral and acidic values in the river and floodplains respectively. Dissolved oxygen values recorded in stations on the floodplains were significantly lower than the values of riverine stations. The nutrient values (nitrate and phosphate) were high.

Table 2 shows the percentage composition of cyanobacteria in the different sampled stations. Seventeen species of cyanobacteria were identified. The dominant cyanobacteria included Oscillatoria rubescens, O. splendida, O. Limnetica, Anabaena spirodides, Aphanizomenon flos-aquae and Microcystis flosaquae. The highest cyanobacteria abundance was recorded in Station V were total abundance reached values of $1.7 \times 10^{5}$ cells $/ \mathrm{L}$ while the lowest values were recorded in Station II (Fig. 1). Analysis of variance showed that cyanobacteria abundance was significantly higher in the stations located on the floodplains than those on the open river $(\mathrm{p}<0.01)$. Cyanobacteria abundance was also significantly $(\mathrm{p}<0.05)$ higher during the wet season than the dry season (Fig. 2) in all the stations except Station VI. However, the densities of $M$. aeruginosa and A. flos-aquae were higher during the dry than wet season in Station III $(\mathrm{p}<0.05)$. 


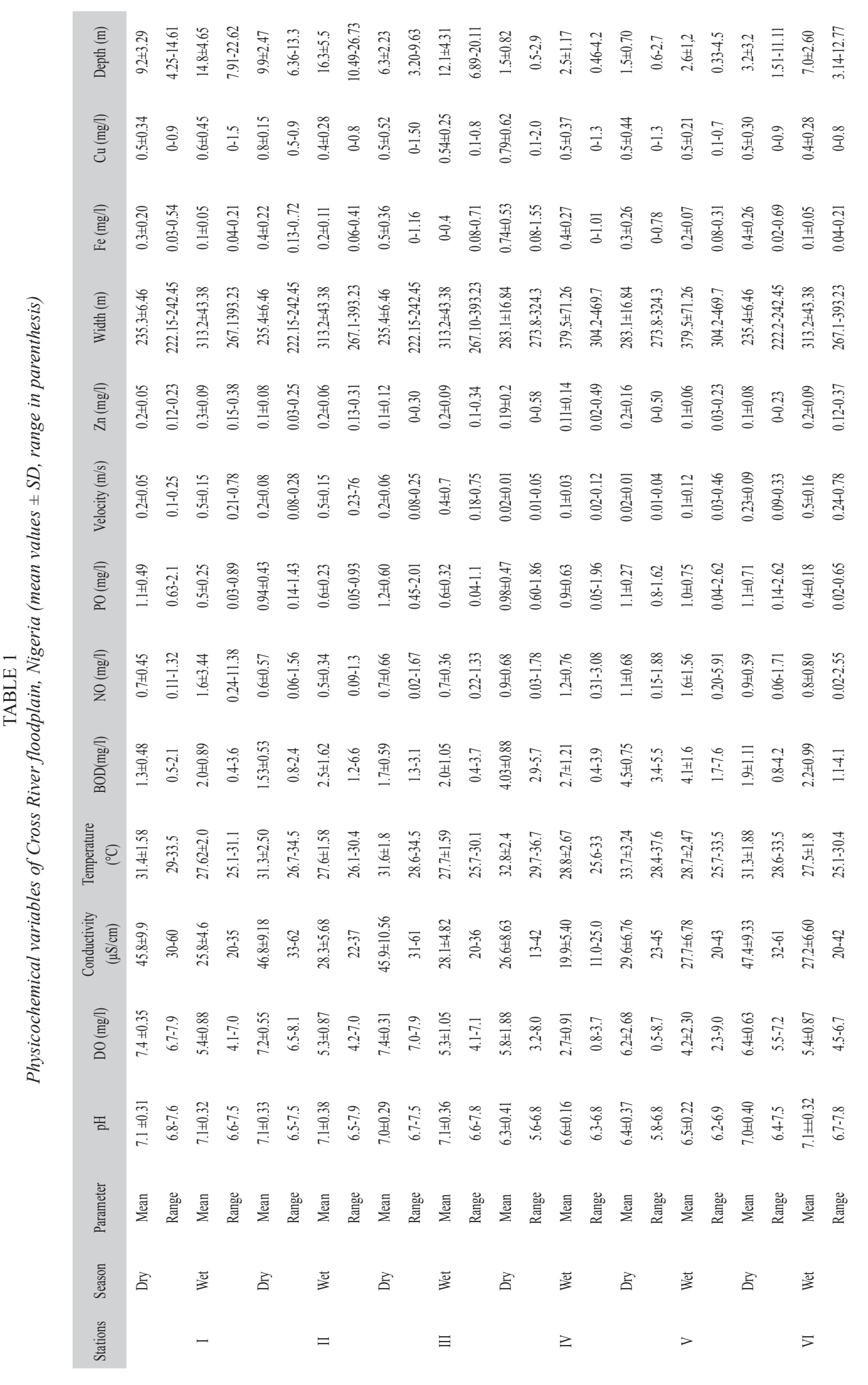


TABLE 2

Percentage composition of cyanobacteria in the different stations of Mid-Cross River

\begin{tabular}{|c|c|c|c|c|c|c|c|}
\hline \multirow{2}{*}{ Taxa } & \multicolumn{7}{|c|}{$\%$} \\
\hline & I & II & III & IV & V & VI & Total \\
\hline \multicolumn{8}{|l|}{ Order: Chroococcales } \\
\hline \multicolumn{8}{|l|}{ Family: Chroococcaceae } \\
\hline Anacystis sp. & 3.36 & 5.91 & 6.79 & 4.43 & 4.23 & 3.03 & 5.06 \\
\hline Gomphosphaeria sp. & 5.18 & 3.28 & 6.08 & 4.31 & 4.12 & 3.03 & 4.96 \\
\hline Microcystis flos aquae & 7 & 9.19 & 8.93 & 5.83 & 6.43 & 3.21 & 6.12 \\
\hline M. aeruginosa & 5.11 & 4.46 & 14.3 & 5.04 & 6.43 & 4.33 & 6.03 \\
\hline Dactylococcoppsis acicularis & 2.69 & 4.99 & 2.86 & 4.48 & 0.64 & 2.17 & 4.02 \\
\hline \multicolumn{8}{|l|}{ Order: Oscillatoriales } \\
\hline \multicolumn{8}{|l|}{ Family: Oscillatoriaceae } \\
\hline Lyngbya contorta & 4.31 & 0 & 3.57 & 4.2 & 4.18 & 2.9 & 4.78 \\
\hline Oscillatoria rubescens & 8.68 & 7.94 & 5.36 & 6.5 & 5.89 & 6.07 & 6.11 \\
\hline O. splendida & 0 & 0 & 0.46 & 8.52 & 8.3 & 0 & 6.47 \\
\hline O. limnetica & 11.6 & 9.19 & 17.9 & 25.2 & 18.7 & 26 & 14.6 \\
\hline Phormidium ambiguum & 6.73 & 9.51 & 5.18 & 2.8 & 4.28 & 6.28 & 4.87 \\
\hline P. subclyindrica & 8.01 & 7.81 & 4.25 & 4.48 & 5.89 & 5.16 & 5.56 \\
\hline$P$. sp. & 6.12 & 7.22 & 4.29 & 2.8 & 3.21 & 3.68 & 4.45 \\
\hline Spirulina laxissima & 0 & 1.31 & 1.07 & 0 & 3.64 & 0.87 & 3.49 \\
\hline \multicolumn{8}{|l|}{ Order: Nostocales } \\
\hline \multicolumn{8}{|l|}{ Family: Nostocaceae } \\
\hline Anabaena spiroides & 10.1 & 11.8 & 6.79 & 7 & 6.48 & 6.67 & 6.53 \\
\hline A. spiroides var crassa & 0 & 0 & 0 & 0 & 5.14 & 0 & 3.75 \\
\hline A. subcylindrica & 8.55 & 9.19 & 6.08 & 7.11 & 5.95 & 4.94 & 6.27 \\
\hline Aphanizomenon flos-aquae & 12.5 & 8.2 & 6.11 & 7.28 & 6.43 & 21.7 & 6.98 \\
\hline
\end{tabular}

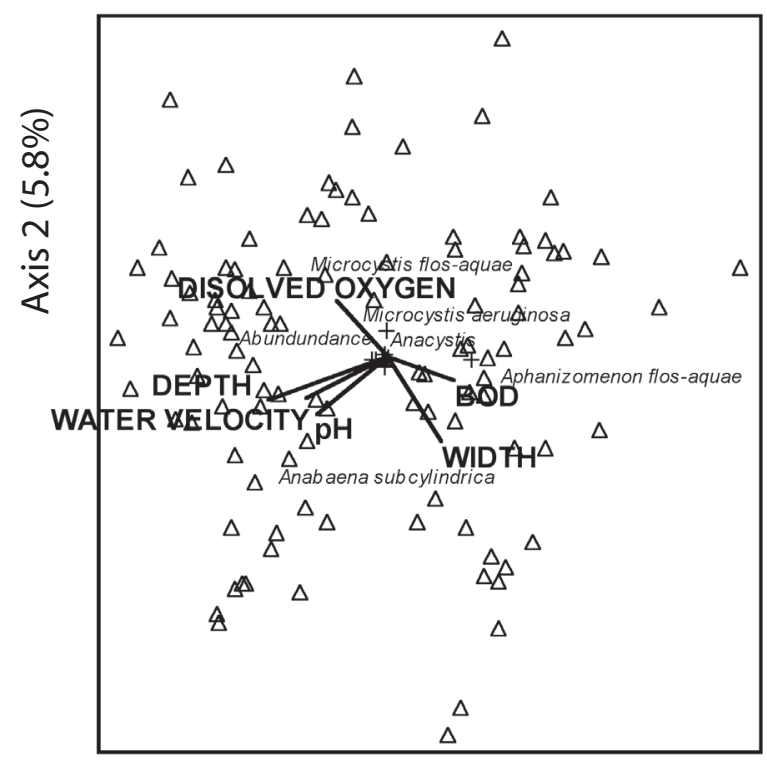

Axis 1 (37.1\%)

Fig. 1. Spatio-temporal variations in cyanobacteria abundance in Mid-Cross River. 


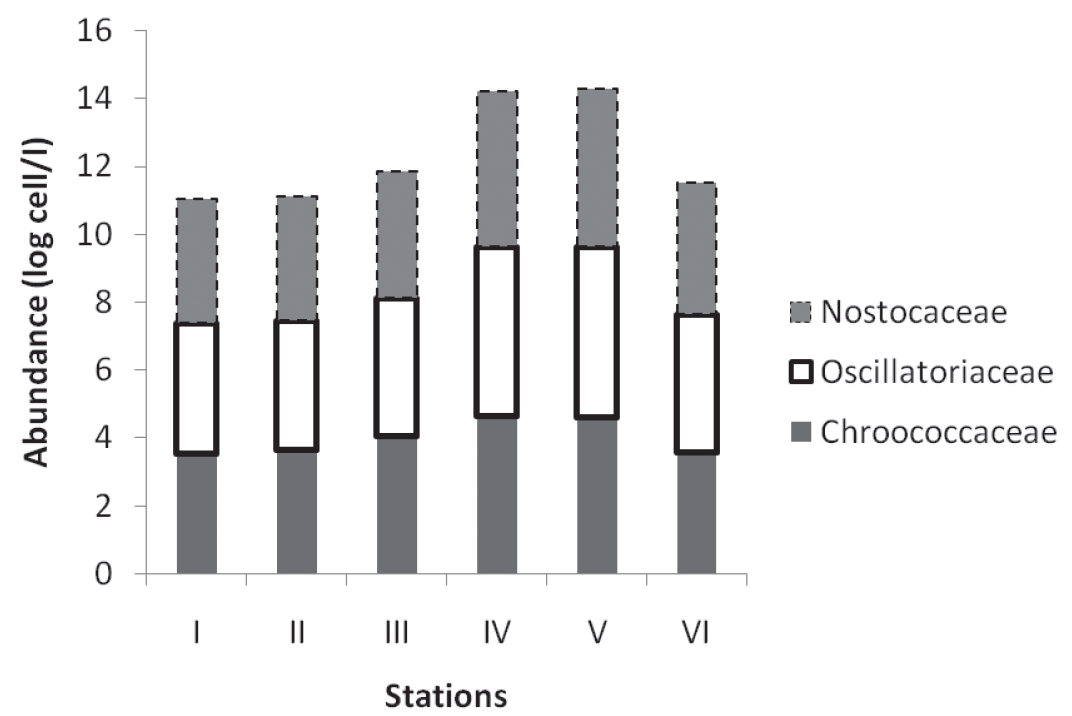

Fig. 2. Cyanobacteria abundance of the different families.

Fig. 3 shows the biplot of a canonical analysis (CCA). The first two axis of the Canonical correspondence analysis (CCA) explained $42.9 \%$ of cyanobacteria-environment relationship. The first axis was negatively correlated with $\mathrm{pH}(\mathrm{r}=-0.51)$, dissolved oxygen $(r=-0.37)$, water velocity $(r=-0.59)$, conductivity $(\mathrm{r}=-0.34)$ and depth $(\mathrm{r}=-0.86)$ and positively with width $(\mathrm{r}=0.40)$ and biological oxygen demand $(\mathrm{r}=0.48)$. The second axis was positively correlated with oxygen $(\mathrm{r}=$ $0.40)$ and negatively correlated with $\mathrm{pH}(\mathrm{r}=$ $-0.42)$ and width $(r=-0.62)$. The wet season was characterized by increased river width and depth, low conductivity and reduced oxygen content, whereas cyanobacteria abundance was high especially $O$. limnetica and $M$. flos-aquae. During the dry season conductivity and oxygen content were high and water velocity, depth and width were low and cyanobacteria abundance was low especially $O$. limnetica.

\section{DISCUSSION}

The wide variation recorded in $\mathrm{pH}$, dissolved oxygen, water depth and velocity was probably due to spatial variation in these variables especially between the lotic and lentic ecosystems. The lentic stations (Stations IV and V) are located close to agricultural lands and frequently received organic fertilizer runoffs. The decomposition of these and litters from riparian vegetations could be responsible for the low $\mathrm{pH}$ and oxygen content of the lakes as suggested by del Giorgio et al. (1991). Seasonal variations in rainfall could be responsible for the wide variation in water depth and velocity, as these variables are strongly linked to meteorological conditions in tropical waters (Aoyagui and Bonecker 2004). Electrical conductivity of the Mid- Cross was very low and consistent with what has been recorded for the Upper and Lower Cross (Moses 1979, Akpan and Offem 1993). It was lower than that of most Nigerian rivers and other tropical rivers (Ovie and Adeniji 1994, Phiri 2000, Akin-Oriola 2003, Obire et al. 2003, Mokaya et al. 2004). It was within the range of River Modder (Koning et al. 2000). In contrast, the phosphate and nitrate values were higher than $0.008-0.02 \mathrm{mg} / \mathrm{L}$ and $0-0.8 \mathrm{mg} / \mathrm{L}$ respectively recorded by Moses (1979) and mean values of $0.07 \mathrm{mg} / \mathrm{L}$ (phosphate) and $1.02 \mathrm{mg} / \mathrm{L}$ (nitrate) reported by Akpan (1993). In fact, there was 


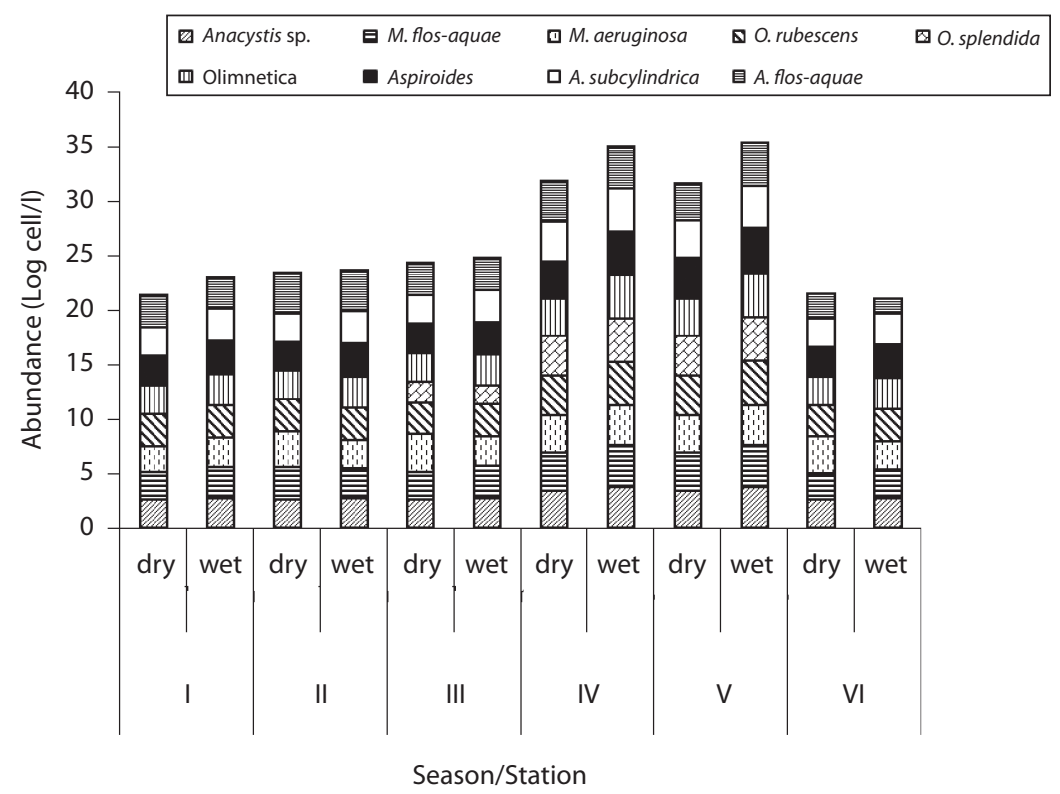

Fig. 3. Biplot of a canonical analysis of cyanobacteria/environment relationship.

ten-fold increase in phosphate from the 1992 values, indicating increased eutrophication of the Cross River ecosystem. This is probably due to increase in anthropogenic activities (notable agriculture and sewage disposal) near the river. Increased phosphate level of the river will definitely give competitive advantage to the cyanobacteria over diatoms and green algae. The growth of cyanobacteria is P-limited principally due to the ability of several species to fix nitrogen (Blomqvist et al. 1994). Several studies revealed that cyanobacteria are generally poor competitors for phosphorous in comparison to diatoms and green algae (Sterner 1994, Fujimoto et al. 1997). This is probably why they rarely dominate oligotrophic waters (Downing et al. 2001). Consequently, increase in phosphate will favour increased cyanobacteria abundance. The trace metals were fairly high but below the EPA (2006) standards. High metal values could be as a result of runoffs from pockets of illegal zinc-copper mining activities around the Cross River basin. Values were particularly higher in the floodplains than in the open water due to proximity of the floodplains to the mines.
Cyanobacteria abundance was fairly high between seasons and stations. This may be attributed to the presence of still waters in the several ponds and lakes within the Cross River floodplain with conditions conducive for the proliferation of these plankton groups. Still blackwater was suggested by del Giorgio et al. (1992) to be the likely sources of cyanobacteria bloom in rivers. In line with this, cyanobacteria abundance was remarkably higher in the lakes than in the open water. High cyanobacteria abundance in the lake was mainly attributed to crustacean grazing activities, which depleted the smaller edible algae to the advantage of the cyanobacteria (Okogwu 2008). Cyanobacteria are known to be less palatable and less attractive to zooplankton (especially cladocerans), so they receive little grazing attention (Relevante and Gilmartin 1982, Repka 1996). In cladoceran dominated lakes, cyanobacteria are known to have high densities as the grazing activities of this group of zooplankton effectively eliminate other competing alga from the phytoplankton community. This may explain the higher density of cyanobacteria recorded during the wet season compared to the dry 
season in most of the stations as cladoceran density attained peak in these lakes during the wet season (Okogwu 2008). The density of green algae and diatom was reported to be very low during this period (wet season) (Okogwu 2008). Grazing zooplankton remove their natural competitors (small alga) releasing nutrients to them (Repka 1996). However cyanobacteria are generally harmful to zooplankton by clogging their feeding apparatus, toxin production and poor nutritional quality of the cells (DeMott et al. 2001, Sterner and Elser 2002, Jang et al. 2003). Therefore, the cyanobacteria abundance recorded in the floodplains of the Cross River should be of concern as these are the breeding grounds of the important fishes of the river notably Chrysichthys nigroditatus, Clarias gariepinus Oreochromis niloticus and Tilapia zilli during the wet season. Fish larvae exposed to cyanobacterial toxin showed reduced feeding and growth rate (Baganz et al. 1998).

Canonical correspondence analysis (CCA) showed a strong correlation between cyanobacteria abundance and the water quality variables; $\mathrm{pH}, \mathrm{BOD}$, dissolved oxygen, water velocity and width. There was a positive significant correlation between water width and cyanobacteria abundance $(0.36, \mathrm{p}<0.05)$. During the wet season, the river extends its width and connects with the lakes leading to exchange of biotic and abiotic materials as well as mild increase in the mixing of water column. Under this condition available literature (Reynolds 1997, Huisman 1999) showed that cyanobacteria may have competitive advantage over diatoms and green algae. The buoyant cyanobacteria float upwards forming gradually a bloom that shades their competitors from light. It is also possible that the interaction between the lentic and lotic ecosystems of Cross River during the wet seasons lead to inoculation of the riverine stations with cyanobacteria from the floodplains. Cyanobacteria negatively correlated with oxygen content $(-0.37, \mathrm{p}<0.01)$ and $\mathrm{pH}(-0.51, \mathrm{p}<0.01)$. This may be attributed to high degradation of dead cyanobacteria subsequent to blooms leading to oxygen depletion and reduced $\mathrm{pH}$; this reasserts the findings of Richardson (1997). The positive significant relationship between cyanobacteria and BOD further buttresses this point. Huisman and Hulot (2005) stated that die-off of surface cyanobacteria bloom in Lake Nieuwe Meer resulted in disgusting smell and anoxia. Cyanobacteria blooms therefore have serious adverse effects on other aquatic biota especially fish larvae and zooplankton and humans. The negative correlation between cyanobacteria and $\mathrm{pH}$ may be explained by the fact that cyanobacteria growth is inhibited at low pH (Shapiro 1997). It has been suggested that an effective way of managing cyanobacteria in freshwater is by reducing $\mathrm{pH}$ in addition to decreasing eutrophication (Huisman and Hulot 2005). From Fig. 3, it could be deduced that Microcystis flos-aquae, Microcystis aeruginosa and Aphanizomenon subcylindrica were more susceptible to low $\mathrm{pH}$ than Anabaena subcylindrica.

High phosphate, nitrate and trace metals and low N:P have been widely reported as major factors limiting cyanobacteria bacteria abundance (Elser et al. 1990, del Giorgio 1991, Akin-Oriola 2003). However, CCA analysis showed no significant correlation between these parameters and cyanobacteria of Cross River floodplain. This therefore validates the views of Ibelings and Maberly (1998) that in eutrophic waters factors other than nutrients may limit cyanobacteria growth. Consequently factors influencing cyanobacteria bloom may be ecosystem-dependent ranging from hydrographic to trophic related variables. In order to reduce the abundance of cyanobacteria in the Mid-Cross River to protect the fisheries, drinking water quality and recreational value of the region, management strategy should include reduction in $\mathrm{pH}$ and nutrient enrichment and biomanipulation.

\section{RESUMEN}

Las variables físico-químicas y la abundancia de cianobacterias del río nigeriano Mid-Cross fueron estudiadas en seis estaciones entre marzo del 2005 y agosto del 2006. El Análisis de Correspondencia Canónica (CCA) demostró que la demanda biológica de oxígeno (DBO), oxígeno 
disuelto, $\mathrm{pH}$, velocidad de agua, anchura y profundidad son factores ambientales importantes que influyen en la abundancia de cianobacterias. Los mayores valores de trazas de metales, fosfatos y nitratos, en comparación con estudios previos, indican mayor eutrofización, pero tienen poca correlación con la abundancia de las cianobacterias. La mayor abundancia de cianobacterias se registró durante el periodo más húmedo de la estación seca en la mayoría de las estaciones de muestreo. Las cianobacterias dominantes incluyen Microcystis aeruginosa, Aphanizomenon flosAquae, Oscillatoria limnetica y Anabaena spiroides. Las toxinas producidas por estas especies podrían degradar la calidad del agua. Los factores que favorecen la abundancia de cianobacterias fueron identificados como el aumento de $\mathrm{pH}$, ancho y profundidad. El aumento de la abundancia se asoció con una reducción de oxígeno disuelto y un aumento de los valores de DBO.

Palabras clave: río Cross, llanura de inundación, cianobacterias, calidad del agua, Nigeria.

\section{REFERENCES}

Akin-Oriola, G.A. 2003. On the phytoplankton of Awba reservoir, Ibadan, Nigeria. Rev. Biol. Trop. 51: 9-16.

Akpan, E.R. \& J.O. Offem. 1993. Seasonal variations in water quality of the Cross River, Nigeria. Rev. Hydrobiol. Trop. 26: 95- 103.

Akpan, E.R. 1993. Seasonal cycles of phytoplankton and grazing activity in the Cross River system of south eastern Nigeria. Trop. Ecol. 34: 143-149.

Aoyagui, A.S.M. \& C.C. Bonecker. 2004. Rotifers in different environments of the upper Parana River floodplain (Brazil): richness, abundance and the relationship to connectivity. Hydrobiologia 522: 281-290.

APHA. 1992. Standard methods for the examination of water and wastewater. American Public Health Association, Washington, D.C., USA. 1268 p.

Baganz, D., G. Staaks \& C. Steinberg. 1998. Impact of the cyanobacteria toxin, microcystin-LR on behaviour of zebra fish, Danio rerio. Wat. Res. 32: 948-952.

Blomqvist, P., A. Pettersson \& P. Hyenstrand. 1994. Ammonium-nitrogen: A key regulatory factor causing dominance of non-nitrogen-fixing cyanobacteria inaquatic systems. Arch. Hydrobiol. 132: 141-164.

del Giorgio, P.A., A.L. Vinocur, R.J. Lombardo \& H.G. Tell. 1991. Progressive changes in the structure and dynamics of the phytoplankton community along a pollution gradient in a lowland river- a multivariate approach. Hydrobiologia 224: 129-154.
DeMott, W. \& F. Moxter. 1991. Foraging on cyanobacteria by copepods: responses to chemical defenses and resource abundance. Ecology 72: 1820-1834.

DeMott, W.R., R.D. Gulati and E. van Donk. 2001. Daphnia food limitation in three hyperhypereutrophic Dutch lakes: evidence for exclusion of large-bodied species by interfering filaments of cyanobacteria. Limnol. Oceanogr. 46: 2054-2060

Downing, J.A., S.B. Watson \& E. McCauley. 2001. Predicting cyanobacteria dominance in lakes. Can. J. Fish. Aquat. Sci. 58: 1905-1908

Elser, J.J., E.R. Marzolf \& C.R. Goldman. 1990. Phosphorous and nitrogen limitations in the freshwaters of North America: a review and critique of experimental enrichments. Can. J. Fish. Aquat. Sci. 47: $1468-1477$

EPA (United States Environmental Protection Agency) 2006. National recommended water quality criteria. EPA 4304T, Washington, DC.

Fujimoto, N., R. Sudo, N. Sugiura \& Y. Inamori. 1997. Nutrient-limited growth of Microcystis aeruginosa and Phormidium tenue and competition under various N:P supply ratios and temperature. Limnol. Oceanogr. 42: 250-256.

Hansson, L., S. Gustafsson, K. Rengefors \& L. Bomark. 2007. Cyanobacterial chemical warfare affects zooplankton community composition. Freshwat. Biol. 52: $1290-1301$.

Huisman, J. \& F.D. Hulot. 2005. Population dynamics of harmful cyanobacteria: factors affecting species composition. In J. Husiman, H.C.P Matthijs \& P.M. Visser (eds.). Harmful cyanobacteria. Springer, Berlin, Germany.

Huisman, J. 1990. Population dynamics of light-limited phytoplankton: microcosm experiments. Ecology 80 : 202-210.

Hyenstrand, P., P. Blomqvist \& A. Pettersson. 1998. Factors determining cyanobacterial success in aquatic systems - a literature review. Arch. Hydrobiol. 51: 41-62.

Ibelings, B.W., \& S.C Maberly. 1998. Photoinhibition and the availability of inorganic carbón restrict photosynthesis by surface blooms of cyanobacteria. Limnol. Oceanogr. 43: 408-419.

Jang, M.H., K. Ha, G.J. Joo and N. Takamura. 2003. Toxin production of cyanobacteria is increased by exposure to zooplankton. Freshwat. Biol. 48: 1540-1550. 
Karjalainen, M., M. Reinikainen, L. Spoof, J.A.O. Meriluoto, K. Sivonen \& M. Viitasalo. 2005. Trophic Transfer of Cyanobacterial Toxins from Zooplankton to Planktivores: Consequences for Pike Larvae and Mysid Shrimps. Environ. Toxicol. 20: 354-362.

Keating, K.I 1977. Allelopathic influence on blue-green bloom sequence in a eutrophic lake. Science 196: 885-887

Koning, N., J.C. Roos \& J.U. Grobbelaar. 2000. Water quality of the Modder River, South Africa. Afr. J. Aqu. Sci. 25: 202-210.

Kozlowsky-Suzuki, B., M. Karjalainen, M. Lehtiniemi, J. Engström-Öst, M. Koski \& P. Carlsson. 2003. Feeding, reproduction and toxin accumulation by the copepods Acartia bifilosa and Eurytemora affinis in the presence of the toxic cyanobacterium Nodularia spumigen. Mar. Ecol. Prog. Ser. 249: 237-249

Landsberg, J.H. 2002. The effects of harmful algal blooms on aquatic organisms. Rev. Fish. Sci. 10:113-390

Lehtiniemi, L., J. Engstrom- Ost, M. Karjalainen, B. Kozlskwy-Suziki \& M. Viitasalo. 2002. Fate of cynobacterial toxin in the pelagic food web: transfer to copepod or fecal pellets. Mar. Ecol. Prog. Ser. 241: $13-21$.

Maitland, P.S. 1978. Biology of Freshwaters. Blackie, London, England. 244p

Mitrovic, S.M., L.C. Bowling \& R.T. Buckney. 2001 Vertical disentrainment of Anabaena ircinalis in the turbid, freshwater Darling River, Australia: quantifying potential benefits from buoyancy. J. Plank. Res. 23: 47-55.

Mokaya, S.K., J.M. Mathooko \& M. Leichtfried. 2004. Influence of anthropogenic activities on water quality of a tropical stream ecosystem. Afr. J. Ecol. 42: 281-288.

Moses, B.S. 1979. The Cross River; its ecology and fisheries. Proceedings of the international Conference on Kainji Lake and River Basin Development in Africa. New Bussa. Niger. 365-367.

Mur, L.R., O.M. Skulberg \& H. Utkilen. 1999. Cyanobacteria in the environment. In I. Chorus \& J. Bartram (eds.). Toxic cyanobacteria in water. A guide to their public health consequences, monitoring and management. E. \& F. N. Spon, London, England.

Nizan, S., C. Dimentman \& M. Shilo 1986. Acute toxic effects of the Cyanobacterium Microcystis aerugi- nosa on Daphnia magna. Limnol. Oceanogr. 31: 497-502.

Oberholster, P.J., A. Botha \& E.T. Cloete. 2005. An overview of toxic freshwater cyanobacteria in South Africa with special reference to risk, impact and detection by molecular marker tools. Biokemistri 17: $57-71$.

Obire, O. D.C. Tamuno \& S.A. Wemando. 2003. The physiochemical quality of Elechi Creek in Port Harcourt, Nigeria. J. Appl. Sci. Env. Mgt. 7: 43-49.

Okogwu, O.I. \& A.O. Ugwumba. 2006. The zooplankton and environmental characteristics of Ologe Lagoon, Southwest, Nigeria. The Zoologist. 3: 86-92.

Okogwu, O.I. 2008. The physicochemistry, plankton and ichthyofauna of Mid-Cross River-floodplain ecosystem, southeast, Nigeria. Ph.D. Thesis, Ibadan, Nigeria. 210p

Ovie, S. I. 1997. The Ecology and culture of the Zooplankton of Jebba Lake, Nigeria. Ph.D. Thesis, Benin, Nigeria. 212 p.

Ovie, S.I. \&Adeniji, H.A. 1994. Zooplankton and environmental characteristics of Shiroro Lake at the extremes of its hydrological cycle. Hydrobiologia 286: $175-182$.

Phiri, C. 2000. An assessment of the health of two rivers within Harare, Zimbabwe on the basis of the macro invertebrate community structure and selected physicochemical variables. Afr. J. Aqu. Sci. 25: 134-145.

Pushparaj, B., E. Pelosi \& F. Ju"ttner. 1999. Toxicological analysis of the marine cyanobacterium Nodularia harveyana. J. Appl. Phyco. 10: 527-530.

Repka, S. 1996. Inter and intraspecific differences in Daphnia life histories in response to 2 food sources: the green alga Scenedesmus and the filamentous cyanobacterium Oscillatoria. J. Plank. Res. 18: 1213 1223.

Revelante, N. \& M. Gilmartin. 1982. Dynamics of phytoplankton in the Great Barrier Reef lagoon. J. Plank. Res. 4: 47-76.

Reynolds C.S. 1997. Vegetation processes in the pelagic: a model for ecosystem theory. Ecology Institute, Oldendorf, Germany.

Reynolds, C.S., R.L. Oliver \& A.E. Walsby. 1987. Cyanobacterial dominance: the role of buoyancy 
regulation in dynamic lake environment. N. Z. J. Mar. Freshwat. Res. 21: 379-390.

Richardson, K. 1997. Harmful or exceptional phytoplankton blooms in the marine ecosystem. Adv. Mar. Biol. 31: 301-385.

Robarts, R.D. \& T. Zohary. 1987. Temperature effects on photosynthetic capacity, respiration, and growth rates of bloom-forming cyanobacteria. N. Z. J. Mar. Freshwat. Res. 21: 379-399.

Shapiro, J. 1990. Current beliefs regarding dominance by blue-greens: The case for the importance of $\mathrm{CO}_{2}$ and pH. Verh. Int. Verein. Limnol. 24: 38-54.

Shapiro, J. 1997. The role of carbon dioxide in the initiation and maintenance of blue-green dominance in lakes. Freshwat. Biol. 37: 307-323

Smith, V. H. 1986. Light and nutrient effects on the relative biomass of blue-green algae in lake phytoplankton. Can. J. Fish. Aquat. Sci. 43: 148-153.
Sterner, R.W. \& J.J. Elser. 2002. Ecological stoichiometry: The biology of elements from molecules to the biosphere. Princeton, Princeton, New Jersey, USA.

Sterner, R.W. 1989. Resource competition during seasonal succession toward dominance by cyanobacteria. Ecology 70: 229-245.

Sterner, R.W. 1994. Seasonal and spatial patterns in macroand micronutrient limitation in Joe Pool Lake, Texas. Limnol. Oceanogr. 39: 535-550.

Suikkanen, S., O. Giovana, B. Fistarol \& E Grane'lib. 2004. Allelopathic effects of the Baltic cyanobacteria Nodularia spumigena, Aphanizomenon flos-aquae and Anabaena lemmermannii on algal monocultures. J. Exp. Mar. Biol. Ecol. 308: 85-101.

Ugwumba, O.A. \& A.A. Ugwumba. 1993. A study of the physico-chemical hydrology and plankton of Awba Lake in Ibadan, Nigeria Fisheries. Acadbiz Comm. 1: $20-39$. 
